\title{
A rare case of craniopagus parasiticus delivered vaginally at a district hospital
}

\author{
Komal Kuldeepsingh Chhabra*
}

Department of Obstetrics and Gynecology, Government Medical College Khandwa, Madhya Pradesh, India

Received: 31 March 2019

Revised: 15 June 2019

Accepted: 16 July 2019

\section{*Correspondence:}

Dr. Komal Kuldeepsingh Chhabra,

E-mail: doc.komalobgy@gmail.com

Copyright: $\odot$ the author(s), publisher and licensee Medip Academy. This is an open-access article distributed under the terms of the Creative Commons Attribution Non-Commercial License, which permits unrestricted non-commercial use, distribution, and reproduction in any medium, provided the original work is properly cited.

\begin{abstract}
Craniopagus Parasiticus is a very rare type of parasitic twinning. It has an incidence of only 4-6/10,00,000 births. Most of the babies with Craniopagus Parasiticus are still born with only few cases which survived after postpartum surgical separation. In Craniopagus Parasiticus the head of one of the twins is parasitic and protrudes from the head of the normal twin with an undeveloped or underdeveloped body. The skulls of the twins are fused but the body of one of the twins is not developed. The developed twin is known as the auto site while the undeveloped twin is the parasite. Age of the mother or certain nutritional factors have been implicated in the etiology of this type of twinning. This is a rare case report of a female baby with a parasitic craniopagus delivered vaginally at this district hospital. The patient was a fourth gravida 28 year old. There was antenatal polyhydramnios. The patient delivered preterm a still born female baby with a parasitic co-twin. In this case the heads of the twins were fused in temporal and parietal areas while the body of the parasitic twin was completely undeveloped. It was a morphologically female baby with rudimentary labia. The causes of Craniopagus Parasiticus are still not known. Scientists and researchers are continuing work to determine these and also to improve the prognosis and chances of post-surgical survival of these twins. Till present day however there have been only limited number of studies on Craniopagus Parasiticus owing to the rarity of the cases.
\end{abstract}

Keywords: Auto site, Craniopagus parasiticus, Dominant twin, Parasitic twin, Polyhydrsmnios

\section{INTRODUCTION}

Craniopagus Parasiticus is a rare type of parasitic twinning with an incidence of only 4-6/10,00,000 births. ${ }^{1,2}$ Only 11 cases of Craniopagus Parasiticus have been reported in literature so far. ${ }^{2-4}$ Most of the babies with Craniopagus Parasiticus are still born with only 4 cases in which the babies have survived after postpartum surgical separation.

In craniopagus parasiticus the head of one of the twins is parasitic with an undeveloped or underdeveloped body. The skulls of the twins are fused but the body of one of the twins is not developed. ${ }^{1,2}$, The developed twin is known as the auto site while the undeveloped twin is the parasite. The etiology of Craniopagus Parasiticus is not yet known on account of the rarity of the cases. Research is still going on to find out the cause of this defect and to author prove prognosis of the babies after surgical separation. This is a rare case report of a female baby with a parasitic craniopagus delivered vaginally at this district hospital.

\section{CASE REPORT}

A 28 year old multigravida (gravid 4 para 4) woman at 35 weeks and 3 days of menstrual age presented to this district hospital with complaints of pain in abdomen. There was no history of bleeding or leaking per vagina. There was no family history of congenital anomalies or 
anomalies in previous children. She had 3 full term vaginal deliveries of children which were alive and healthy. She had 4 antenatal visits during which she was screened for human immunodeficiency virus (HIV), hepatitis B virus (HBV), syphilis (VDRL) and diabetes along with 2 antenatal scans. In the scans however she was diagnosed to have an anencephalic baby with gross polyhydramnios (AFI> $28 \mathrm{~cm}$ ). She had received tetanus immunization along with iron, folic acid and calcium supplementation during the antenatal period. There was no history of exposure to any teratogen.

On per abdomen examination the fundal height was more than the period of gestation, she was getting 2-3 contractions in 10 minutes lasting for 10-15 seconds and fetal heart rate was 120 beats per minute. On per vaginal examination cervical os was $1.5 \mathrm{~cm}$ dilated, $30 \%$ effaced, central with intact membranes. Labor progressed uneventfully and she delivered a female fetus vaginally after 8 hours of admission. The female baby was then discovered to have 2 heads which was antenatally diagnosed to be anencephaly and weighed around $1.7 \mathrm{~kg}$. The baby was shifted to NICU immediately but could not survive till the referral to a higher centre was arranged. The vaginal delivery was easy without need of episiotomy and without any perineal trauma. There was no PPH or perineal or periurethral tear.

On gross examination the calvarium was absent and the fetal skulls were attached at the temporal region. The orbits were underdeveloped too. The labia were hypoplastic and the contiguous pinnae were fused. (See Figure 1)

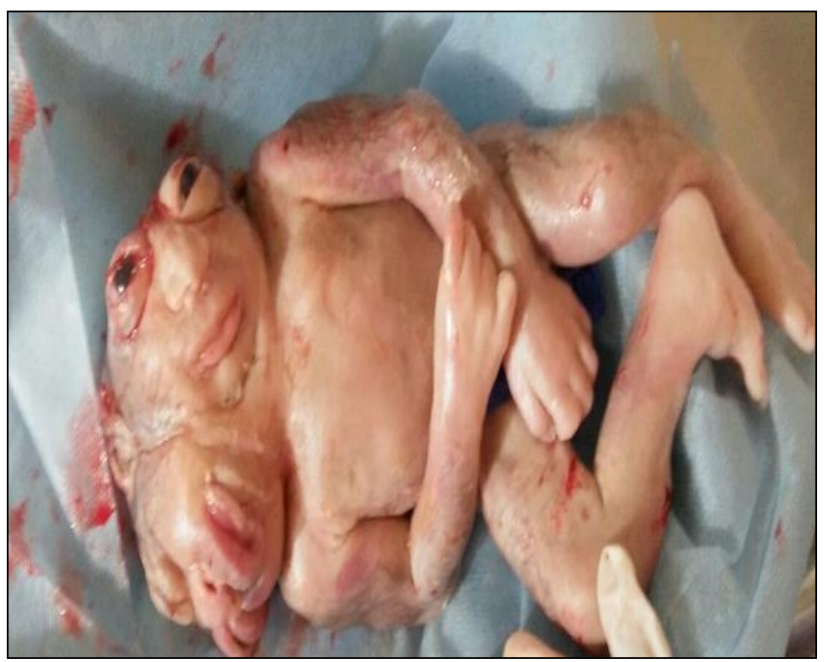

Figure 1: Anterior view of craniopagus parasitic twins.

\section{DISCUSSION}

Craniopagus parasiticus is a very rare type of conjoined twinning with union only at the heads. The difference between parasitic twins and conjoined twins is that the parasitic twin is unable to develop in utero. The skull of one of the twins is attached to the temporal area of the skull of the other twin. In the development of monozygotic twins if the splitting occurs during blastocyst stage two inner cell masses form so that the resulting twins have the same placenta and chorions but distinct amnions. Sometimes the egg may divide into two, but the blastocyst may be one and hence the inner cell mass and the twins share the same chorion, placenta and amnion. This could be the mechanism behind conjoined twins. ${ }^{1,5,6}$ When the twins fail to completely separate into two the dominant embryo develops fully but the other embryo is severely restricted developmentally., ${ }^{3,7}$ The fission theory for development of craniopagus parasitic states that a single zygote leads to development of two foetuses, but separation fails during the second or fourth week of gestation. Another theory states that craniopagus is caused by lack of blood supply to the second twin due to degeneration of the umbilical cord. ${ }^{2,6}$ Only 11 cases of craniopagus parasiticus have been reported so far in literature. ${ }^{1,2,4}$ Most of these cases are still born. Recently a few cases of craniopagus parasiticus have been successfully separated surgically and are surviving till date..$^{2,3,7}$

In this case the pregnant woman was antenatally diagnosed to have anencephaly with polyhydramnios and had an uneventful vaginal delivery at 35 weeks 4 days of menstrual age. This centre being a district hospital (FRU) is not equipped with either pediatric surgery specialists or an intensive care set-up required for a separation procedure. Hence, author had to refer the baby to a higher centre. But the baby could not make it till the referral. Author also could not perform pathological evaluation of the parasitic twin or the aberrant twinning mechanism as the parents could not afford to send the fetus to higher centre for the same.

\section{CONCLUSION}

The cause of craniopagus parasiticus is not known. It also poses a diagnostic problem unless a very high level of suspicion is maintained and with long term experience. The survival in these cases is very low. Genetic researches might help find the exact etiology of the condition and either prevent its occurrence or improve prognosis. Similarly, advancements in pediatric surgery with accurate separation of the twins may ensure better survival of the dominant twin in majority of the cases. Author hope that in near future such facilities could be made available at level of this hospital too so that author too can ensure the survival of these babies. Availability of a dedicated pediatric surgery unit at hospitals like ours is of great help because a large volume of pediatric population can benefit from it.

Funding: No funding sources

Conflict of interest: None declared

Ethical approval: Not required 


\section{REFERENCES}

1. Kansal R, Kale C, Goel A. Craniopagus parasiticus: a rare case. J Clin Neurosci. 2010;17(10):1351-2.

2. Nega W, Damte M, Girma Y, Desta G, Hailemariam M. Craniopagus parasiticus-a parasitic head protruding from temporal area of cranium: a case report. J Med Case Rep. 2016;10(1):340.

3. Wang TM, Li BQ, Li-Che, Fu CL. Craniopagus parasiticus: a case report of a parasitic head protruding from the right side of the face. Br J Plast Surg.1982;35(3):304-11.

4. Bondeson J, Allen E. Craniopagus parasiticus. Everard Home's Two Headed Boy of Bengal. Surg Neurol.1989;31(6):426-34.
5. Aquino DB, Timmons C, Burns D, Lowichik A. Craniopagus Parasiticus: a case showing its relationship to craniopagus conjoined twinning. Pediatr Pathol Lab Med. 1997;17(6):939-44.

6. Nair KR. Craniopagus parasiticus. Surg Neurol. 1990;33(2):159.

7. Wang DM, Zhang PL. A case report of craniopagus parasiticus (clinical features and histological study of the accessory brain). Zhongua Zheng Xing Shao Shang WaiKeZa Zhi.1985;1(1):31-3.

Cite this article as: Chhabra KK. A rare case of craniopagus parasiticus delivered vaginally at a district hospital. Int J Reprod Contracept Obstet Gynecol 2019;8:3425-7. 